\title{
PEMANFAATAN LIMBAH BIJI DURIAN (Durio zibethinus) SEBAGAI SUBSTRAT ALTERNATIF PEMBUATAN TEMPE BIJI DURIAN DENGAN PERBANDINGAN KADAR RAGI DAN LAMA FERMENTASI
}

\author{
Utilization Of Durian Seeds (Durio zibethinus) As An Alternative Substrate For Making \\ Tempe Of Durian Seeds With Comparison Of Year And Old Fermentation Levels
}

\author{
Khisbul Maulana El Romadhon ${ }^{1}$, Deny Utomo ${ }^{1}$ \\ Jurusan Ilmu dan Teknologi Pangan, Universitas Yudharta Pasuruan \\ Jalan Yudharta No. 07 Sengonagung Purwosari Pasuruan 67162 \\ Email: denyut369@gmail.com
}

\begin{abstract}
ABSTRAK
Tempe merupakan produk pangan yang sangat populer di Indonesia yang diolah dengan proses fermentasi kedelai dalam waktu tertentu menggunakan jamur Rhizopus oligosporus. Limbah biji durian (Durio zibethinus) menjadi substrat alternatif pada pembuatan tempe merupakan suatu inovasi pengganti kedelai dalam pembuatan tempe. Disini telah dilakukan penelitian terhadap tempe biji durian, dengan variabel yang diteliti : kadar ragi dan lama fermentasi. Berdasarkan hasil analisis kimia dan uji organoleptik diperoleh tempe biji durian yang disukai konsumen yaitu pada perlakuan F3R3 (proporsi $2 \%$ kadar ragi dan 72 jam lama fermentasi : 100 gr biji durian).

Kata kunci: tempe biji durian, kadar ragi, lama fermentasi.
\end{abstract}

\begin{abstract}
Tempe is a food product that is very popular in Indonesia which is processed with a fermentation process in a certain time using Rhizopus oligosporus mushrooms. The waste of durian seeds (Durio zibethinus) into an alternative substrate in the manufacture of tempe is an innovation material in making tempeh. Here we have conducted research on durian seed tempeh, with the variables studied: yeast levels and fermentation duration. Based on the results of chemical analysis and organoleptic tests obtained by durian seed tempeh by consumers, namely the F3R3 treatment (danger of $2 \%$ yeast content and 72 hours of fermentation time: $100 \mathrm{~g}$ of durian seeds).
\end{abstract}

Keywords: tempe of durian seeds, yeast content, fermentation duration

\section{PENDAHULUAN}

Bahan pangan alami adalah bahan pangan yang berasal dari sumber hayati, baik yang diolah maupun yang tidak diolah dan diperuntukkan bagi konsumsi manusia. Sumber pangan dapat berasal dari hewan (sumber pangan hewani) dan dari tumbuhtumbuhan (sumber pangan nabati). Salah satu sumber pangan nabati adalah tempe (Mawaddah, 2011).

Tempe merupakan produk pangan yang sangat populer di Indonesia yang diolah dengan proses fermentasi kedelai dalam waktu tertentu menggunakan jamur Rhizopus oligosporus. Secara umum tempe mempunyai ciri berwarna putih karena pertumbuhan miselia-miselia jamur yang menghubungkan antara biji-biji kedelai, sehingga terbentuk tekstur tempe yang kompak.

Indonesia merupakan negara produsen tempe terbesar di dunia dan menjadi pasar kedelai terbesar di Asia. Tempe telah dikonsumsi oleh anak-anak hingga orang tua (Hayati, 2009). Namun akhir-akhir ini harga kedelai yang cenderung mahal menyebabkan biaya produksi tempe semakin besar sehingga nilai jual tempe juga tinggi. Oleh karena itu diperlukan terobosan untuk mengolahnya menjadi sumber makanan 
(Silvia, 2009).. Salah satunya adalah biji durian.

Biji durian cukup berpotensi sebagai sumber gizi, yaitu mengandung protein, karbohidrat, lemak, kalsium dan fosfor. Zat gizi yang terkandung dalam 100 gram biji buah durian antara lain karbohidrat sebanyak 28,3 gram, mineral sebanyak 67 gram, energi $520 \mathrm{KJ}$ atau setara 124,8 kalori, lemak 2,5 gram, protein 2,5 gram, dan serat 1.4 gram. Sedangkan setiap 100 gram kedelai memiliki 331 kal kalori, 34,9 gram protein, 34.8 gram karbohidrat, 227 miligram kalsium, 585 miligram fosfor, 8 miligram zat besi dan 1,1 miligram vitamin B1 (L Ambarita, 2015). Kandungan gizi yang relatif lengkap pada biji durian memungkinkan dapat digunakan untuk pemanfaatan sebagai substrat produksi tempe biji durian.

Tempe adalah makanan yang dihasilkan dari proses fermentasi kapang golongan Rhizopus. Pembuatan tempe membutuhkan bahan baku kedelai. Melalui proses fermentasi, komponen-komponen nutrisi yang kompleks pada kedelai dicerna oleh kapang dengan reaksi enzimatis dan dihasilkan senyawa-senyawa yang lebih sederhana (Wisnu, 2009).

Inokulum tempe merupakan kumpulan spora kapang yang memegang peranan penting dalam pembuatan tempe karena dapat mempengaruhi mutu tempe yang dihasilkan. Jenis kapang memegang peranan utama dalam pembuatan tempe adalah Rhizopus oligosporus dan Rhizophus orizae, sedangkan jenis kapang lain yang terdapat juga adalah Rhizopus stolonifer dan Rhizopus arrhizus (Salma, 2009).

\section{METODE}

Penelitian ini menggunakan rancangan acak kelompok (RAK) dengan perlakuan perbandingan kadar ragi dan lama fermentasi yang digunakan., yaitu $1 \%$ kadar ragi : 24 jam lama fermentasi, 1,5\% kadar ragi : 24 jam lama fermentasi, $2 \%$ kadar ragi : 24 jam lama fermentasi 1\% kadar ragi : 48 jam lama fermentasi, 1,5\% kadar ragi : 48 jam lama fermentasi, 2\% kadar ragi : 48 jam lama fermentasi, $1 \%$ kadar ragi : 72 jam lama fermentasi, 1,5\% kadar ragi : 72 jam lama fermentasi, 2\% kadar ragi : 72 jam lama fermentasi. Masing-masing perlakuan diulang sebanyak 3 kali ulangan sehingga diperoleh 27 percobaan. Data yang diperoleh dianalisis dengan uji sidik ragam dan dilanjutkan uji beda nyata terkecil (BNT) 5 $\%$.

\section{HASIL DAN PEMBAHASAN Analisis Kadar Protein}

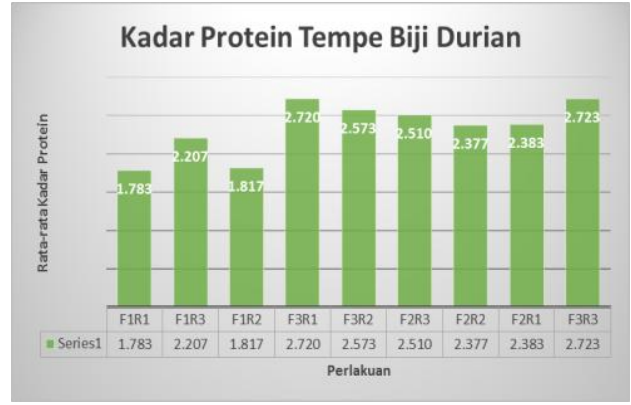

Gambar 1. Grafik Kadar Protein Tempe Biji Durian

Gambar 1. memperlihatkan bahwa perlakuan yang mempunyai kadar protein terendah diperoleh dari perlakuan F1R1 (kadar ragi 1\%, lama fermentasi 24 jam: 100 gr biji durian) sebesar $1,783 \%$. Kadar protein tertinggi diperoleh pada perlakuan F3R3 (2 \% kadar ragi dan 72 jam lama fermentasi: 100 gr biji durian) sebesar 2,723 $\%$

Menurut Hesseltine (1965 dalam Deliani 2008) penyebab terjadinya penurunan kadar protein akibat fermentasi adalah jamur Rhizopus oligosporus bersifat proteolitik dan ini penting dalam pemutusan 
protein. Jamur ini akan mendegradasi protein selama fermentasi menjadi peptide dan seterusnya menjadi senyawa $\mathrm{NH}_{3}$ dan $\mathrm{N}_{2}$ yang hilang melalui penguapan. Dengan semakin lama fermentasi berarti semakin lama kesempatan jamur mendegradasi protein, sehingga protein yang terdegradasipun semakin banyak, akibatnya protein tempe semakin menurun. Pendapat ini juga didukung oleh penelitian Morita dan Handoyo (2006) yang menyatakan bahwa protein akan terdegradasi atau dihidrolisis selama proses fermentasi. Kadar protein akan naik hingga 24 jam, kemudian mengalami proses pendewasaan akibat adanya enzim, karena lama fermentasi mengakibatkan produksi enzim yang lebih rendah ditunjukkan oleh perubahan warna tempe menjadi coklat, sedangkan fermentasi yang belum mengalami proses pendewasaan atau matang akan berwarna putih dan memiliki produksi enzim yang maksimum.

\section{Analisis Kadar Lemak}

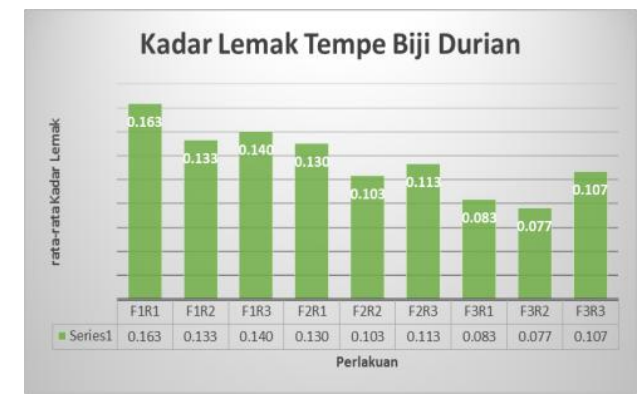

Gambar 2. Grafik Analisis Kadar Lemak

Gambar 2. menunjukkan bahwa perlakuan yang mempunyai kadar lemak terendah diperoleh oleh perlakuan F3R2 (1,5\% kadar ragi dan 72 jam lama fermentasi : 100 gr biji durian) sebesar $0,077 \%$. Kadar lemak tertinggi diperoleh pada perlakuan F1R1 (1\% kadar ragi dan 24 jam lama fermentasi : 100 gr biji durian) sebesar $0,163 \%$. Semakin cepat waktu fermentasi maka akan menghasilkan tempe biji durian dengan kadar lemak tinggi. Menurut Rahayu, et al, (1989) menguraikan karakteristik Rhizopus oligosporus yakni mempunyai aktivitas enzim lipase yang tinggi, sehingga dapat mendegradasi lemak dalam biji durian menjadi asam-asam lemak dan menggunakannya sebagai sumber energi untuk pertumbuhan.

\section{Analisis Tekstur}

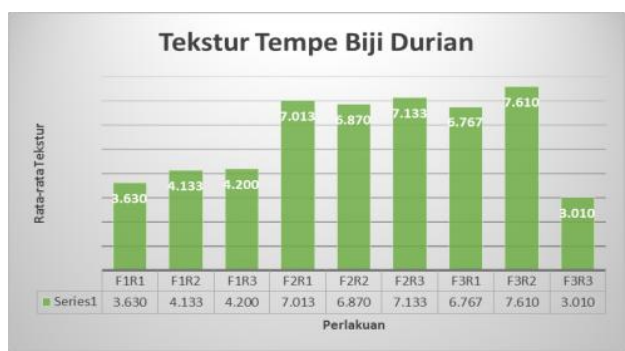

Gambar 3. Grafik Analisa Tekstur

Gambar 3. menunjukkan bahwa perlakuan yang mempunyai kadar lemak terendah diperoleh oleh perlakuan F3R3 (2\% kadar ragi dan 72 jam lama fermentasi : 100 gr biji durian) sebesar 3,010 N. Tekstur tertinggi diperoleh pada perlakuan F3R2 (2\% kadar ragi dan72 jam lama fermentasi :
100 gr biji durian) sebesar 7,610 N. Semakin lama waktu fermentasi dan semakin tinggi kadar ragi maka akan menghasilkan tempe biji durian dengan tekstur yang baik. Tekstur tempe dipengaruhi oleh kandungan protein dan air. Di dalam matriks tempe, molekul $\mathrm{CO}_{2}$ berinteraksi dengan molekul protein 
melalui ikatan nonkovalen yaitu ikatan hidrogen dan hidrofobik. Interaksi antara molekul $\mathrm{CO}_{2}$ superritis dengan protein mengakibatkan protein terdenaturasi. Menurunnya kadar air karena terekstraksi oleh $\mathrm{CO}_{2}$ tekanan tinggi mendukung terbentuknya tekstur elastis. Menurut Aquila, dkk (2006), tekstur bahan dipengaruhi oleh kadar air dan komponen penyusun bahan pangan.

\section{Analisis Sensori Terhadap Rasa}

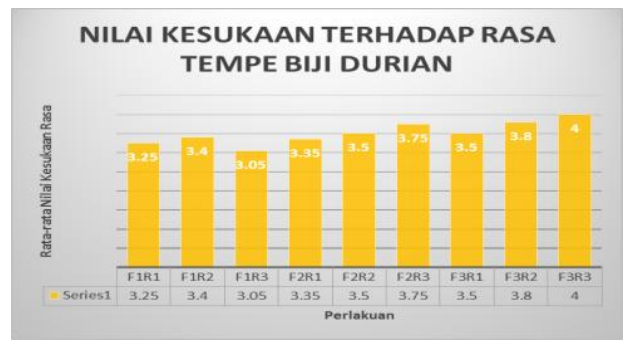

Gambar 4. Analisis Sensori Terhadap Rasa

Gambar 4. memperlihatkan rata-rata nilai kesukaan panelis terhadap rasa tempe biji durian mempunyai persentase terendah yaitu perlakuan F1R3 (proporsi 2\% kadar ragi dan 72 jam lama fermentasi : 100 gr biji durian) dengan nilai sebesar 3,05, sedangkan persentase tertinggi terhadap rasa tempe biji durian yaitu perlakuan F3R3 (proporsi 2\% kadar ragi dan 72 jam lama fermentasi : 100 gr biji durian) yaitu dengan nilai sebesar 4 yang berarti menyukai.
Dari hasil pengamatan di atas dapat disimpulkan bahwa semakin tinggi penambahan kadar ragi dan semakin lama waktu fermentasi maka tempe biji durian yang dihasilkan semakin disukai panelis. Hal ini disebabkan karena karakteristik dari Rhizopus oligosporus yang dapat menghasilkan aroma dan flavor spesifik (Rahayu, 1989).

\section{Analisis Sensori Terhadap Warna}

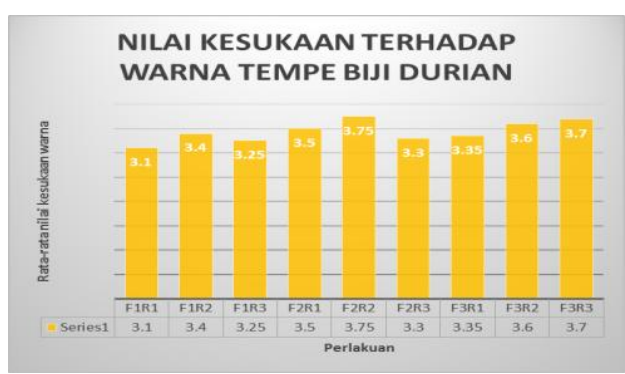

Gambar 5. Grafik Analisis Sensori Terhadap Warna

Gambar 5. memperlihatkan rata-rata nilai kesukaan panelis terhadap warna tempe biji durian mempunyai persentase terendah yaitu perlakuan F1R1 (proporsi 1\% kadar ragi dan 24 jam lama fermentasi : 100 gr biji durian) dengan nilai sebesar 3,1, sedangkan persentase tertinggi terhadap warna tempe biji durian yaitu perlakuan F3R3 (proporsi $2 \%$ kadar ragi dan 72 jam lama fermentasi :
100 gr biji durian) yaitu dengan nilai sebesar 3,7 yang berarti menyukai.

Dari hasil pengamatan di atas dapat disimpulkan bahwa semakin tinggi penambahan kadar ragi dan semakin lama waktu fermentasi maka tempe biji durian yang dihasilkan semakin disukai panelis. Hal ini disebabkan karena karakteristik Rhizopus oligosporus yang dapat menghambat pertumbuhan, sporulasi dan pembentukan 
aflatoksin dari Aspergillus flavus dan A. parasiticus (Rahayu, 1989).

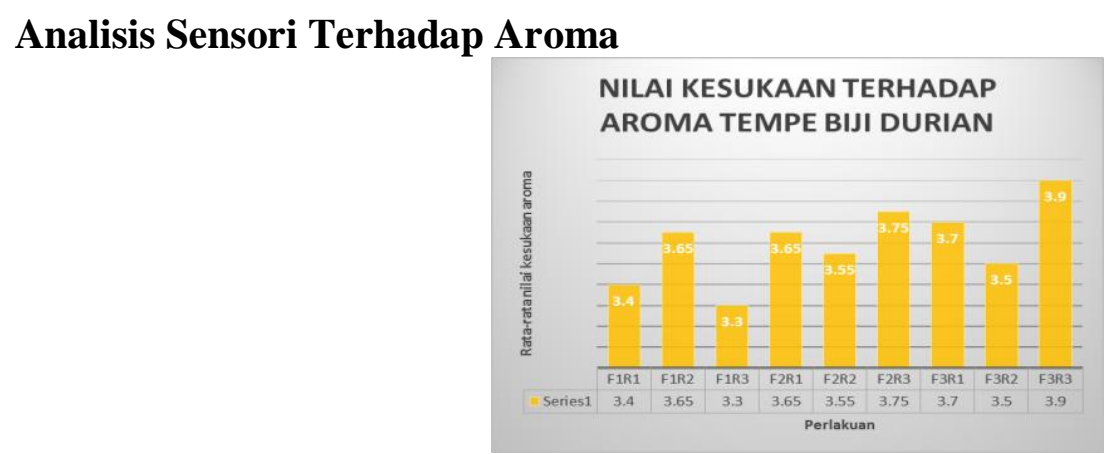

Gambar 6. Grafik Analisis Sensori Terhadap Aroma

Gambar 6. memperlihatkan rata-rata nilai kesukaan panelis terhadap aroma tempe biji durian mempunyai persentase terendah yaitu perlakuan F1R3 (2\% kadar ragi dan 24 jam lama fermentasi : 100 gr biji durian) dengan nilai sebesar 3,3, sedangkan persentase rata-rata nilai terhadap aroma tertinggi yaitu perlakuan F3R3 (2\% kadar ragi dan 72 jam lama fermentasi : 100 gr biji durian) dengan nilai sebesar 3,9 yang berarti menyukai.

Dari hasil pengamatan diatas dapat disimpulkan bahwa semakin tinggi kadar ragi dan semakin lama waktu fermentasi tidak mempengaruhi terhadap aroma tempe biji durian yang dihasilkan. Hal ini disebabkan karena tempe mengandung antioksidan yang dapat menghambat pengembangan ketengikan, tetapi hanya dapat bertahan 1-2 hari karena sporulasi kapang dapat menyebabkan perubahan warna produk dan aroma amonia hasildari proses proteolysis. Produksi tempe dapat meningkatkan daya terima produk oleh konsumen karena aroma dan rasa yang menyenangkan (Adam dan Moss, 2008).

\section{Analisis Sensori Terhadap Tekstur}

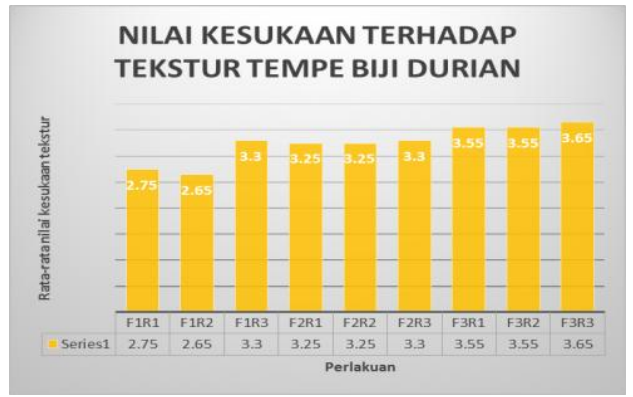

Gambar 7. Grafik Analisis Sensori Terhadap Tekstur

Gambar 7. memperlihatkan rata-rata nilai kesukaan panelis terhadap tekstur tempe biji durian mempunyai persentase terendah yaitu perlakuan F1R2 (1,5\% kadar ragi dan 48 jam lama fermentasi : 100 gr biji durian) dengan nilai sebesar 2.65, sedangkan rata-rata nilai kesukaan panelis terhadap tekstur tertinggi yaitu perlakuan F3R3 (2\% kadar ragi dan 72 jam lama fermentasi : 100 gr biji durian) dengan nilai sebesar 3.65 yang berarti menyukai.

Dari hasil pengamatan diatas dapat disimpulkan bahwa semakin tinggi persentase kadar ragi dan semakin lama waktu fermentasi mempengaruhi produk tempe biji durian yang dihasilkan. Hal ini disebabkan karena pada perebusan terjadi hidrasikarena air mengalami difusi ke dalam bijikacang. Perebusan kacang-kacangan 
dapatmenyebabkan beberapa perubahan kualitas,baik secara fisik, biokimia, maupun nilaigizinya (Pramita, 2008).

\section{KESIMPULAN}

Berdasarkan penelitian yang dilakukan dapat diambil kesimpulan :

1. Berdasarkan hasil penelitian didapatkan bahwa antara proporsi perbandingan kadar ragi dan lama fermentasi tempe biji durian berpengaruh nyata terhadap tekstur fisik dan tidak berpengaruh nyata kadar protein, kadar lemak serta organoleptik meliputi rasa, warna, aroma dan tekstur.

2. Berdasarkan hasil penelitian didapatkan perlakuan terbaik yaitu perlakuan F3R3 (proporsi $2 \%$ kadar ragi dan 72 jam lama fermentasi : 100 gr biji durian) dengan karakteristik sebagai berikut: rata-rata kadar protein 2,523\%; kadar lemak $0,077 \%$; tekstur $3,27 \mathrm{~N}$; serta ratarata tingkat kesukaan panelis terhadap rasa 4,0 (suka); warna 3,7 (suka); aroma 3,9 (suka) dan tekstur 3,65 (suka).

3. Perlu dilakukan penelitian lanjutan tentang penambahan kadar ragi dan lama fermentasi produk tempe biji durian sehingga dihasilkan produk tempe biji durian yang bermutu baik.

\section{DAFTAR PUSTAKA}

Deliani. (2008). Pengaruh Lama Fermentasi Terhadap Kadar Protein, Lemak, Komposisi Asam Lemak Dan Asam Fitat Pada Pembuatan Tempe. Tesis. Medan: Sekolah Pascasarjana Universitas Sumatera Utara Medan

Hayati, S. (2009). Pengaruh Lama Fermentasi Terhadap Kualitas Tempe dari Biji Nangka (Artocarpus heterophyllus) dan penentuan Dosis Zat Gizinya. Skripsi: Universitas Sumatra Utara.

Mawaddah, L. (2011). Pengaruh Lama Waktu Penyimpanan Terhadap Kualitas Fisik dan Organoleptik Tempe Kedelai. Skripsi: STAIN Palangkaraya.
Rahayu, K., Kuswanto, dan S. Sudarmadji. (1989). Mikrobioogi Pangan. PAU Pangan dan Gizi. Universitas Gadjah Mada: Yogyakarta.

Silvia, I. (2009). Pengaruh Penambahan Variasi Berat Inokulum Terhadap Kualitas Tempe Biji Durian (Durio zibrthinus). Skripsi: Universitas Sumatra Utara Medan.

Sudarmadji, S., B. Haryono, dan Suhardi. (2010). Prosedur Analisa untuk Bahan Makanan dan Pertanian. Yogyakarta: Penerbit Liberty. 